\title{
Distal phalanges of Eosimias and Hoanghonius
}

Daniel L. Gebo ${ }^{a, *}$, K. Christopher Beard ${ }^{b, c}$, Xijun Ni ${ }^{d}$, Marian Dagosto ${ }^{e}$

${ }^{a}$ Department of Anthropology, Northern Illinois University, DeKalb, IL 60115

${ }^{\mathrm{b}}$ Biodiversity Institute, University of Kansas, Lawrence, KS 66045-7561

${ }^{\mathrm{c}}$ Department of Ecology \& Evolutionary Biology, University of Kansas, Lawrence, KS $66045-7561$

${ }^{\mathrm{d}}$ Institute of Vertebrate Paleontology and Paleoanthropology, Chinese Academy of Sciences, Post Office Box 643, Beijing, China 100044

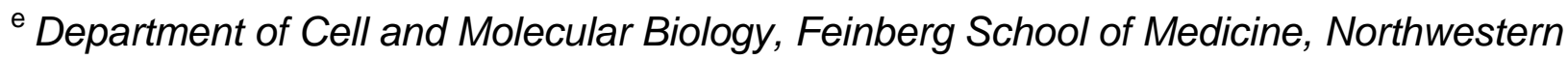
University, Chicago, IL 60611. United States

${ }^{*}$ Corresponding author.

E-mail address: dgebo@niu.edu (D.L. Gebo). 


\section{Abstract}

Seven primate distal phalanges have been identified from two middle Eocene fossil localities (Locality 1 and Nanbaotou) in the Yuanqu Basin, China, providing the first evidence of distal phalangeal morphology in Asian Eocene adapiform and eosimiid primates. The bones are best allocated to the basal anthropoid Eosimias centennicus and to hoanghoniine adapiforms. All distal phalangeal specimens display a morphology consistent with nail-bearing fingers and toes. The hallucal distal phalanx of the basal anthropoid Eosimias is more similar to that of primitive tarsiiforms than to crown group anthropoids. The adapiform distal phalanges from Locality 1 are allocated to Hoanghonius stehlini while those from Nanbaotou are tentatively assigned to an indeterminate hoanghoniine because dental remains of adapiforms have yet to be identified from this site. The distal phalangeal anatomy of hoanghoniines differs slightly from that documented for adapines and notharctines. One distal phalanx from Locality 1 shows a second pedal digit "grooming claw" morphology as noted for notharctines by Maiolino et al. (2012) and cercamoniines by von Koenigswald et al. (2012). 


\section{Introduction}

The recent publications by Gingerich (2012), Maiolino et al. (2012), and von Koenigswald et al. (2012) have heightened interest in distal phalangeal anatomy across fossil primates. The presence or absence of a grooming claw among Eocene fossil primates is central to this discussion, but it also bears on functional characteristics relating to grasping. To date, this discussion has focused geographically on North American and European fossils. This contribution adds some new Asian fossils to this debate.

Locality 1 and Nanbaotou are late middle Eocene fossil localities in the Yuanqu Basin, southern Shanxi Province, central China (Zdansky, 1930; Beard et al. 1996; Gebo et al., 1999; Beard and Wang, 2004). Both sites occur in the Zhaili Member of the Heti Formation (Beard and Wang, 2004) and both document a low level of primate diversity. Only two species of fossil primates are known from an abundant sample of teeth and jaws at Locality 1 (Zdansky, 1930; Beard et al., 1996; Tong et al., 1999; Beard and Wang, 2004), while only a single species has so far been described from Nanbaotou (Phenacopithecus xueshii, an eosimiid; Beard and Wang, 2004). At Locality 1, Hoanghonius stehlini is a relatively large adapiform primate (Qi and Beard, 1998) that has been estimated to weigh approximately $700 \mathrm{~g}$ (Fleagle, 2013), whereas Eosimias centennicus, a basal anthropoid, is much smaller, weighing between 91-179 g (Beard et al., 1996). Given the size disparity and the low level of primate species diversity at Locality 1 and Nanbaotou, it should be simpler to affiliate isolated primate postcranial elements from the Yuanqu Basin with taxa based on dental remains, in contrast to the 
more complicated situation that characterizes the Shanghuang fauna (see Gebo et al., 2012). In 1999, the first sivaladapid postcranial element, a first metatarsal attributed to Hoanghonius stehlini, was described from Locality 1 (Gebo et al., 1999). Subsequently, a small primate talus from the same locality was attributed to Eosimias centennicus by Gebo et al. $(2000,2001)$. Here we report on seven primate distal phalanges that were recently recovered from Locality 1 and Nanbaotou.

At Locality 1, three distal phalanges have been recovered to date (Fig. 1; Table 1). IVPP V 12797 is the largest of the three distal phalanges from Locality 1, and it coincides in absolute length with lateral manual phalanges of Saimiri sciureus, a 6201,200 g sized primate (Jack, 2007). We attribute this lateral phalanx to the larger species known at Locality 1, Hoanghonius stehlini, a hoanghoniine sivaladapid. The second specimen, IVPP V 12798, is shorter and can be identified as a hallucal distal phalanx, being similar in length to hallucal distal phalanges of Tarsius syrichta, a primate weighing between 95-153 g (Dagosto et al., 2003). We attribute this specimen to the basal anthropoid Eosimias centennicus. The third specimen from Locality 1 , IVPP V12783.3, is also short, being a little over $2 \mathrm{~mm}$ in length, but this specimen compares favorably to second pedal digits associated with adapiform fossil primates (see Maiolino et al., 2012; von Koenigswald et al., 2012). Based on its morphology, we assign this third specimen to an adapiform fossil primate, likely Hoanghonius stehlini (see below).

At Nanbaotou, we have recovered four lateral distal phalanges (Fig. 2; Table 1) that are morphologically similar to the largest specimen from Locality 1 (IVPP V 12797). We therefore assign these four specimens from Nanbaotou to an indeterminate 
hoanghoniine fossil primate, although dental remains attributed to this taxon have not yet been identified from this site.

IVPP V 12797

The IVPP V 12797 distal phalanx is a flattened nail-bearing bone similar to those of other living and fossil primates (see von Koeningswald et al. [2012] and Maiolino et al. [2012] for images of a variety of living and fossil primate distal phalanges). IVPP V 12797 is a complete lateral distal phalanx (Fig. 1) with a length of $4.4 \mathrm{~mm}$ and a basal width of $2.95 \mathrm{~mm}$ (Table 1; Fig. 3). Lateral phalangeal lengths and basal widths for specimens of Cantius ralstoni, a notharctine fossil primate with an estimated body weight of 1,300 g (Fleagle, 2013), are 4.7 and 2.75 (UW 21447) and 4.85 and $2.9 \mathrm{~mm}$ (UW 21454), respectively (Gebo et al., 1991). Cantius, along with other notharctines (e.g., Notharctus and Smilodectes), appears to have distal phalanges that are relatively narrow and long along the head and apical tuft region compared to the wider and shorter head and tuft of Hoanghonius. Apical tuft expansion in Cantius is noted to be relatively narrower than that of Smilodectes and the cercamoniine Europolemur by Covert (1988), Godinot and Beard (1991), and von Koenigswald et al. (2012). Gregory (1920) notes distal narrowness for Notharctus relative to lemurs as well.

The distal phalangeal head anatomy in IVPP V 12797 is shaped like an arrowhead with a roughened and grooved apical tuft (Fig. 1a). These grooves represent vascular channels via the dorsal nutrient foramina (Maiolino et al., 2012). This roughened shape is shared with notharctine distal phalanges, in contrast to the 
smoother head shape of most other living and fossil primates including Adapis (see Fig. 1 in Godinot, 1992). Notharctines have narrower phalangeal heads with a tall and pronounced triangular wedge shape to the distal aspect of the shaft that rises above the apical tuft before spreading out to the lower apical sides and front. Sagittal elevation of the phalangeal shaft is less evident in IVPP V 12797. Adapine distal phalanges, relative to notharctines (Godinot, 1992), are distinctive in their tall sagittal heights at the shaft and base. Hoanghonius is similar to notharctines in this respect. Distal phalangeal head length in IVPP V 12797 is long, representing 53\% of the absolute length, making the mid-shaft region comparatively short before the wide base. Long distal phalangeal head and apical tuft regions (Fig. 1b) relative to absolute length characterize adapiform primates (Table 2). The hoanghoniine distal phalanges show wider head widths relative to the base compared to other adapiforms (EF/GH; Table 2), and they possess a relatively flatter plantar surface from the base to the ungual rim and ungual tuberosity (Fig. 1b).

The base of the IVPP V 12797 distal phalanx is quite wide, with a base to length ratio of $67 \%$, a typical primate characterization (Table 2 ). Adapiform primate distal phalanges all possess wide nutrient foramina along their medial and lateral sides just distal to the wide base (see Maiolino et al., 2012; Boyer et al., 2013; Maiolino, 2013; these are called cervical foramina in von Koenigswald et al., 2012), as does IVVP V 12797 (Figs. 1c and 4). The medial and lateral epicondylar tubercles are prominent for the collateral ligaments that connect the distal phalanx to the middle phalanx. Interosseus ligaments also attach the tips of these epicondylar tubercles to the corresponding tips of the ungual spines of the phalangeal head. The proximal joint 
surface curves medially and laterally away from the midpoint of the joint. The midpoint is expanded proximally relative to the sides. Flexor and extensor tubercles are located centrally above and below this joint surface.

IVPP V 12798

The IVPP V 12798 distal phalanx attributed to Eosimias centennicus is a flat hallucal distal phalanx with a wide base and a large plantar fossa. The latter is a key identifying feature of a hallucal distal phalanx for the insertion of a prominent flexor hallucis longus tendon (Figs. 1g, h, i and 5). The IVPP V 12798 distal phalangeal head is asymmetrical, allowing the specimen to be identified as a right hallucal distal phalanx. The medial margin of the base is broken. This specimen measures $3.4 \mathrm{~mm}$ in absolute length (Table 1), making it slightly longer than a hallucal distal phalanx (USNM 542001) attributed to Teilhardina brandti $(3.1 \mathrm{~mm})$. The ratio of head length to absolute length ( $A B / A D$; Table 2) is $35 \%$, a value similar to other haplorhine primates but lower than that of Hoanghonius and other adapiforms. The distal phalanges of haplorhine primates appear to be short-headed relative to those of adapiform fossil primates (AB/AD; Table 2). The dorsoventral height of the base of this specimen is also low (IJ/AD; Table 2; Figs. $1 \mathrm{i}$ and 3 ), like that of other haplorhines, in contrast to the often taller shafts of adapiforms. This is especially true for adapines. If we compare distal phalangeal head width to absolute length (EF/AD), the IVPP V 12798 hallucal distal phalanx of Eosimias yields a ratio of 0.44 . This value is similar to galago means (Galagoides demidovii, 0.44 , $n=3$; Galago senegalensis, $0.46, n=9)$ and to the value for Teilhardina brandti $(0.41)$, 
taxa with relatively long shafts. Taxa with wider distal phalangeal heads and shorter phalangeal shafts such as Omomys carteri (0.57; DMNH 52590) and Tarsius syrichta (0.57) show higher values for this index. In contrast, platyrrhines display narrow head widths and long shafts, providing even lower ratio values (e.g., Cebus apella, 0.33; Saimiri sciureus, 0.32 ; Table 2). The length of the flexor fossa relative to absolute length (CD/AD; Table 2) is 37\%, a value similar to Archicebus, Omomys, Tarsius, and Saimiri but lower than values obtained for Cantius, Cebus, or Teilhardina. The IVPP V 12798 base is wide (Fig. $1 \mathrm{~g}, \mathrm{~h}$ ). There is a lateral dorsal nutrient foramen on the phalangeal head of IVPP V 12798 (Fig. 1g) as well as a widely curving groove that demarcates the sides of the distal phalangeal head, with a dorsal region above and a plantar section below. This groove is also noted in Teilhardina brandti (Rose et al., 2011). It is unclear what soft tissue invades this groove (Rose et al., 2011). The medial and lateral epicondylar tubercles are prominent and extend distally beyond the widely curved proximal joint surface and base (Fig 1g). The proximal joint is more convex than concave in lateral view relative to IVPP V12797 (compare Fig. 1c and 1i).

IVPP V 12798 is the first hallucal distal phalanx known from a basal anthropoid, and it appears to be morphologically similar to those of early Eocene tarsiiforms. IVPP V 12798 lacks the reduction of the phalangeal head and apical tuft region as well as the elongated phalangeal shaft of platyrrhines (or crown-group anthropoids). On the other hand, IVPP V 12798 lacks the wide phalangeal head that characterizes middle Eocene Omomys and extant Tarsius. The distal phalangeal shaft of IVVP V 12798 is longer than those of Tarsius (see Fig. 5 in von Koenigswald et al., 2012) and Omomys (DMNH 52,590), as is also the case for Teilhardina and Archicebus. The grasping big toe of 
Eosimias centennicus appears to be morphologically and functionally more similar to those of Teilhardina and Archicebus than to those of living platyrrhines or other crowngroup anthropoids.

IVPP V 12783.3

The IVPP V 12783.3 distal phalanx from Locality 1 (Fig. 1d, e, f) is relatively short (2.05 $\mathrm{mm}$ in length), but its overall morphology suggests an affinity with adapiform fossil primates. At this locality, the only taxon known from dental remains that is a viable candidate for its allocation is Hoanghonius stehlini. Alternative options might be to 1) allocate this small distal phalanx to the small eosimiid at Locality 1 , although this distal phalangeal morphology matches best with other adapiforms and does not appear to be similar in morphology to the grooming claws of tarsiers; or 2) allocate this small phalanx to a small hoanghoniine from Locality 1 . Unfortunately, the known dental record from Locality 1 does not provide any dental support for the presence of a small adapiform at this site to date.

The IVPP V 12783.3 distal phalanx is oblong in overall shape and rounded distally along the edges of the apical tuft (Fig. 1d, e). It lacks the grooved apical tuft of Notharctus (Maiolino et al., 2012), being smoother and flatter in this region. It has a dorsal tubercle and a prominent plantar proximal tubercle (Fig. 1d, e, f). On its plantar surface, there is a short volar process and a long flattened distal apical tuft region (Fig. 1e). The distal end curves upward (Fig. 1f) and is similar to the sharp distal curvature observed in notharctine second digit distal pedal phalanges (see Maiolino et al., 2012; 
von Koenigswald et al., 2012). Maiolino et al. (2012:13) note that "a short volar process combined with a dorsally canted and strongly distally tapering (in height) shaft" distinguishes grooming from ungual distal phalanges, and they argue for a grooming claw on digit two in Notharctus tenebrosus. They further note that Notharctus has a smaller and more proximally positioned flexor tubercle, indicative of less grasping prowess. The plantar flexor tubercle in IVPP V 12783.3 is prominent (Fig. 1f) and larger than is the case in Notharctus. Maiolino et al. (2012) state that the total morphological pattern found in Notharctus is not identical to second digit grooming distal phalanges found among extant lemuriforms, given the apical tuft width that is evident in Notharctus. The same differences from extant lemurs can be found in IVPP V 12783.3.

The IVPP V 12783.3 distal phalanx is morphologically similar to second pedal distal phalanges figured by Maiolino et al. (2012) and von Koenigswald et al. (2012) for other adapiform clades. IVPP V 12783.3 lacks the dorsally grooved and widely splayed apical tuft occurring in second digit pedal distal phalanges of Notharctus (Maiolino et al., 2012) but retains a plantarly shortened volar area and a long and flattened distal section. The distal angle of curvature is steep (Fig. 1f) as in Notharctus (see Maiolino et al., 2012). In some respects, the IVPP V 12783.3 specimen is more similar to the grooming claws attributed to Europolemur (von Koenigswald et al., 2012) than to the second digit specimens of Notharctus. Overall, the presence or absence of grooming claws among adapiforms, relative to lemuriforms, has stimulated a debate among colleagues since the 2012 publications by Maiolino et al. and von Koenigswald et al. concerning the morphology of a "grooming claw" relative to that of a "nailed digit." Perhaps the term "grooming nail" works better as a descriptor for adapiform second 
pedal distal phalanges relative to the long and narrow structure found among lemuriform second digits, given the wider apical tuft region known for all second digit adapiform specimens relative to lemuriforms. Here we have an issue of inference. The proximal region of the second pedal distal phalanges in question is similar in shape and dorsal orientation to those of lemuriform grooming claws, but the width, especially distally with their expanded apical tufts, is unlike the narrow claw-like structure characterizing lemuriform second pedal distal phalanges. Among adapiforms for which these elements are known, the distal phalangeal anatomy of the second pedal digit certainly differs in shape from that of pedal digits 3-5 (see Maiolino et al., 2012; von Koenigswald et al., 2012). However, second pedal digit bony widths suggest a wider covering structure such as a nail, and thus we advocate the use of "grooming nail" for this second digit morphology found among fossil adapiform primates. The different morphological patterns evidenced by the grooming "claws" of adapiforms and lemuriforms raises the question of homology versus evolutionary convergence for these structures, as noted by Gingerich (2012:657) when he states "if Eocene adapoids had grooming claws, then they were different in form from the grooming claws of primates living today."

\section{Nanbaotou}

The four specimens from Nanbaotou (Fig. 2) are all lateral distal phalanges from digits 3-5 (Table 1). They span absolute lengths from 2.1 to $3.65 \mathrm{~mm}$, all less than the $4.4 \mathrm{~mm}$ length of IVPP V 12797, but all appear morphologically similar to the IVPP V 12797 specimen attributed to Hoanghonius stehlini at Locality 1 as noted above. Jaws 
and teeth of adapiforms have yet to be described from Nanbaotou, so we cannot refer these specimens to any specific adapiform taxon presently.

\section{Function and adaptation}

All of the Locality 1 and Nanbaotou distal phalanges indicate nailed digits involved with grasping hands and feet with the exception of IVPP V 12783.3, which likely represents a "grooming claw" or "grooming nail" in our view. Since we cannot distinguish lateral digit manuals (digits 3-5) from lateral pedal distal phalanges (see Mittra et al. [2007] for living primates), we do not know if the lateral distal phalanges attributed to Hoanghonius are from a hand or foot, or both. The flatter shaft and reduced base height found in IVPP V 12797 stand in contrast to known adapine distal phalanges, which show robustly built and heightened shafts capable of absorbing digital grasping forces in a manner different from that of other primates. IVPP V 12797 is best distinguished from notharctines by its wider distal phalangeal head and shorter shaft, and these two features imply a wider digit distally when grasping substrates. Wide finger or toe-tips suggest an expanded area for grips among hoanghoniine sivaladapids relative to notharctine adapiforms, but a soft tissue mechanical correlation is muddled. Hamrick (1998) showed that the width of the apical tuft was correlated with the size of the apical pad in three platyrrhines, and he found that the size of the pad correlated with differential use of arboreal substrates. Subsequently, Mittra et al. (2007) constructed two indices for tuft expansion and for robusticity across a larger sample of living primates. Smaller apical tuft size was associated with arboreal versus terrestrial 
primates. Among the category of arboreal quadrupeds, apical tuft size was not explained by the mechanical strain hypothesis and thus the locomotor category arboreal quadrupedalism did not explain any particular pattern in apical tuft morphology. In contrast, the vertical clinging and leaping category showed expanded apical tufts and a high robusticity mean, implying that large apical tufts are useful when gripping vertical supports. Tarsiers, which are known to possess large and expanded finger and toe tips, were documented by Mittra et al. (2007) to possess more expanded and robust apical tufts than living lemuriforms while platyrrhines had the smallest tufts of all primates sampled.

The distal hallucal phalanx attributed to the basal anthropoid Eosimias also shows a wide digit with a pronounced flexor fossa. Both imply forceful grasping by the hallux. This phalanx shows no bony head reduction or increased shaft length found among living anthropoids with columnar-shaped distal phalanges (see von Koenigswald et al., 2012), suggesting that the IVPP V 12798 specimen functions like the big toes of basal tarsiiforms rather than those of living anthropoids.

In terms of soft tissues, the distal phalanx fascia, ligaments, and tendons as well as the volar skin (Cartmill, 1974, 1979; Shrewsbury and Johnson, 1975; Dykyj, 1989; Lemelin, 2000) have been examined in living primates, and this information can be applied to the Locality 1 and Nanbaotou specimens (see Figs. 4 and 5). On the plantar surface of a primate distal phalanx, tendinous fibers from the long flexor tendon insert onto the proximal base and shaft while also sending fibers to insert on the elevated ridge at the base of the head (Fig. 5). This plantar ridge is evident in both the Locality 1 and Nanbaotou specimens. This ridge is also the spot of the distal arcade of capillary 
blood supply from the plantar digital artery. In terms of circulation, dorsal head nutrient foramina receive vessels from the distal capillary arcade (present in IVPP V 12798), whereas the medial and lateral nutrient foramina (i.e., cervical foramina of von Koenigswald et al., 2012) receive capillary blood flow from the proximal arcade (present in the hoanghoniine specimens). The nail bed begins at the proximal elevation of the dorsal shaft just distal to the dorsoproximo extensor tubercle. Nails cover about twothirds of the distal phalangeal shaft and head dorsally (Fig. 4), and this can be imaged for all fossil distal phalanges. The volar skin of primates is characterized by papillary ridges that are separated by grooves (LeGros Clark, 1936; Biegert, 1961; Cartmill, 1974, 1979; Lemelin, 2000). Primate apical pads are rather large (Martin, 1990) and primates that move and forage on small diameter supports opt for wider distal phalanges and apical pads (Hildebrand, 1995; Hamrick, 1998), making the width of fossil distal phalanges relevant.

\section{Conclusion}

The middle Eocene distal phalangeal specimens from Locality 1 and Nanbaotou display a variety of distinctive primate characteristics indicative of grasping fingers or toes. The nailed distal phalangeal anatomy of hoanghoniines differs slightly from adapines and notharctines, while all adapiforms share distal phalanges that bear long heads, large bilateral nutrient foramina (see Maiolino et al., 2012; Maiolino, 2013; Boyer et al., 2013), and taller shafts relative to Eocene fossil tarsiiforms and basal anthropoids such as eosimiids. The morphology of the second pedal distal phalanx of a specimen 
tentatively identified with Hoanghonius is similar to that of other adapiforms and suggests the presence of a "grooming nail" on this digit among these fossil primates. The hallucal distal phalanx of Eosimias is another bony element that functionally links this basal anthropoid with primitive tarsiiforms, in contrast to crown group anthropoids.

\section{Acknowledgements}

We thank Betty Strack at the Field Museum of Natural History (Chicago) and Dr. Jon Warnock at Northern Illinois University (DeKalb) for the SEM images. Financial support was provided by a series of grants from the National Science Foundation, including BCS 0821644 and BCS 1441585. 


\section{References}

Beard, K.C., Wang, J., 2004. The eosimiid primates (anthropoidea) of the Heti Formation, Yuanqu Basin, Shanxi and Henan Provinces, People's Republic of China. J. Hum. Evol. 46, 401-432.

Beard, K.C., Tong, Y., Dawson, M., Wang, J., Huang, X., 1996. Earliest complete dentition of an anthropoid primate from the Late Middle Eocene of Shanxi Province, China. Science 272, 82-85.

Biegert, J., 1961. Volarhaut der Hände and Füsse. In: Hofer, H., Schultz, A.H., Stark, D. (Eds.), Primatologia 2. Karger, Basel.

Boyer, D.M., Yapuncich, G.S., Chester, S.G.B., Bloch, J.I., Godinot, M., 2013. Hands of early primates. Yrbk. Phys. Anthropol. 57, 33-78.

Cartmill, M., 1974. Pads and claws in arboreal locomotion. In: Jenkins, F.A. (Ed.), Primate Locomotion. Academic Press, New York, pp. 45-83.

Cartmill, M., 1979. The volar skin in primates: its frictional characteristics and their functional significance. Am. J. Phys. Anthropol. 50, 497-509.

Covert, H.H., 1988. Ankle and foot morphology of Cantius mckennai: adaptations and phylogenetic implications. J. Hum. Evol. 17, 57-70.

Dagosto, M., Gebo, D.L., Dolino, C., 2003. The natural history of the Philippine Tarsier (Tarsius syrichta). In: Wright, P., Simons, E., Gursky, S. (Eds.), Tarsiers: Past, Present, and Future, Rutgers University Press, New Brunswick, NJ, pp. 237-259.

Dykyj, D., 1989. Anatomy of the nail. Clin. Podiatric Med. Surg. 6, 215-228. 
Fleagle, J.G., 2013. Primate Adaptation and Evolution. Academic Press, New York. Gebo, D.L., Dagosto, M., Rose, K.D., 1991. Foot morphology and evolution in early Eocene Cantius. Am. J. Phys. Anthropol. 86, 51-73.

Gebo, D.L., Dagosto, M., Beard, K.C., Qi, T., 1999. A first metatarsal of Hoanghonius stehlini from the Late Middle Eocene of Shanxi Province, China. J. Hum. Evol. 37, 801-806.

Gebo, D.L., Dagosto, M., Beard, K.C., Qi, T., Wang, J., 2000. The oldest anthropoid postcranial fossils and their bearing on the early evolution of higher primates. Nature 404, 276-278.

Gebo, D.L., Dagosto, M., Beard, K.C., Qi, T., 2001. Middle Eocene tarsals from China: implications for haplorhine evolution. Am. J. Phys. Anthropol. 116, 83-107. Gebo, D.L., Dagosto, M., Ni, X., Beard, K.C., 2012. Species diversity and postcranial anatomy of Shanghuang primates. Evol. Anthropol. 21, 224-238.

Gingerich, P.D., 2012. Primates in the Eocene. Palaeobio. Paleaeoenv. 92, 649-663.

Godinot, M., 1992. Early euprimate hands in evolutionary perspective. J. Hum. Evol. 22, 267-283.

Godinot, M., Beard, K.C., 1991. Fossil primate hands: a review and an evolutionary inquiry emphasizing early forms. Hum. Evol. 6, 307-354.

Gregory, W.K., 1920. On the structure and relations of Notharctus, an American Eocene primate. Bull. Am. Mus. Nat. Hist. 3, 49-243.

Hamrick, M.W., 1998. Functional and adaptive significance of primate pads and claws: evidence from New World anthropoids. Am. J. Phys. Anthropol.106, 113-128. 
Hildebrand, M., 1995. Analysis of Vertebrate Structure. John Wiley and Sons Inc., New York.

Jack, K.M. The cebines. In: Campbell, C.J., Fuentes, A., Mackinnon, K.C., Panger, M., Bearder, S.K. (Eds.), Primates in Perspective. Oxford University Press, Oxford, pp. 107-123.

LeGros Clark, W.E., 1936. The problem of the claw in primates. Proc. Zool. Soc. 1936, $1-25$.

Lemelin, P., 2000. Micro-anatomy of the volar skin and interordinal relationships of primates. J. Hum. Evol. 38, 257-267.

Maiolino, S., 2013. Morphological variation in adapiform and omomyoid distal phalanges. Am. J. Phys. Anthropol. S56, 187.

Maiolino, S., Boyer, D.M., Bloch, J.I., Gilbert, C.C., Groenke, J., 2012. Evidence for a grooming claw in a North American adapiform primate: implications for anthropoid origins. Plos One 7, 1-28.

Martin, R.D., 1990. Primate Origins and Evolution. Princeton University Press, New Jersey.

Mittra, E.S., Smith, H.F., Lemelin, P., Jungers, W.L., 2007. Comparative morphometrics of the primate apical tuft. Am. J. Phys. Anthropol. 134, 449-459.

Qi, T., Beard, K.C., 1998. Late Eocene sivaladapid primate from Guangxi Zhuang Autonomous Region, People's Republic of China. J. Hum. Evol. 35, 211-220.

Rose, K.D., Chester, S.G.B., Dunn, R.H., Boyer, D.M., Bloch, J.I., 2011. New fossils of the oldest North American euprimate Teilhardina brandti (Omomyidae) from the Paleoeocene-Eocene thermal maximum. Am. J. Phys. Anthropol. 146, 281-305. 
Shrewsbury, M., Johnson, R.K., 1975. The fascia of the distal phalanx. J. Bone Joint Surg. Am. 57, 784-788.

Tong, Y.-S., Wang, J.-W., Huang, X.-S., 1999. Discovery of a nearly complete lower jaw of Hoanghonius stehlini Zdansky, 1930 (Mammalia, Primates). Vertebrata PalAsiatica 37, 290-314.

Von Koenigswald, W., Habersetzer, J., Gingerich, P., 2012. Pedal distal phalanges of the Eocene adapoids Europolemur and Darwinius compared to phalanges of Notharctus and other primates. Palaeobio. Paleaeoenv. 92, 539-565.

Zdansky, O., 1930. Die altteriären Saugetiere Chinas nebst stratigraphischen Bemerkungen. Palaeontol. Sinica 6, 1-87. 


\section{Figure captions}

Figure 1. Locality 1 distal phalanges. Left (a, b, c): IVPP V 12797 (lateral digit 3-5, Hoanghonius stehlini); Middle (d, e, f): IVPP V 12783.3 (second pedal digit); and Right (g, h, i): IVPP 12798 (hallux, Eosimias centennicus). Dorsal (a, d, g), plantar (b, e, h), and lateral $(\mathrm{c}, \mathrm{f}, \mathrm{i})$ views. Scale $=1 \mathrm{~mm}$.

Figure 2. Nanbaotou distal phalanges. Left: IVPP 12783.4 (lateral digit 3-5); Right: IVPP 12783.6 (lateral digit 3-5). Dorsal (a), plantar (b), and lateral (c) views. Scale $=1$ $\mathrm{mm}$.

Figure 3. Distal phalangeal measurements (A-J).

Figure 4. Dorsal view of anatomical features associated with a distal phalanx.

Figure 5. Plantar view of anatomical features associated with a distal phalanx. 
Table 1. Distal phalangeal measurements ${ }^{a}$

\begin{tabular}{|c|c|c|c|c|c|c|c|}
\hline Site & $\begin{array}{l}\text { Locality } \\
1\end{array}$ & $\begin{array}{l}\text { Locality } \\
1\end{array}$ & $\begin{array}{l}\text { Locality } \\
1\end{array}$ & Nanpoutou & Nanpoutou & Nanpoutou & Nanpoutou \\
\hline Identification & $\begin{array}{l}\text { IVPP V } \\
12797 \\
\end{array}$ & $\begin{array}{l}\text { IVPP V } \\
12798 \\
\end{array}$ & $\begin{array}{l}\text { IVVP V } \\
12783.3\end{array}$ & $\begin{array}{l}\text { IVPP V } \\
12782.4 \\
\end{array}$ & $\begin{array}{l}\text { IVPP V } \\
12783.4 \\
\end{array}$ & $\begin{array}{l}\text { IVPP V } \\
12783.5 \\
\end{array}$ & $\begin{array}{l}\text { IVPP V } \\
12783.6\end{array}$ \\
\hline Type & $\begin{array}{l}\text { lateral } \\
\text { digit } \\
\text { distal } \\
\text { phalanx }\end{array}$ & $\begin{array}{l}\text { hallucal } \\
\text { distal } \\
\text { phalanx }\end{array}$ & $\begin{array}{r}2^{\text {nd }} \text { digit } \\
\text { pedal } \\
\text { distal } \\
\text { phalanx }\end{array}$ & $\begin{array}{l}\text { lateral } \\
\text { digit } \\
\text { distal } \\
\text { phalanx }\end{array}$ & $\begin{array}{l}\text { lateral } \\
\text { digit } \\
\text { distal } \\
\text { phalanx }\end{array}$ & $\begin{array}{l}\text { lateral } \\
\text { digit } \\
\text { distal } \\
\text { phalanx }\end{array}$ & $\begin{array}{l}\text { lateral } \\
\text { digit } \\
\text { distal } \\
\text { phalanx }\end{array}$ \\
\hline \multicolumn{8}{|l|}{$\begin{array}{l}\text { Measurements } \\
(\mathrm{mm})\end{array}$} \\
\hline $\begin{array}{l}A D \text {, absolute } \\
\text { length }\end{array}$ & 4.4 & 3.4 & 2.05 & 3.65 & 3.25 & 2.1 & 3.25 \\
\hline $\begin{array}{l}A B \text {, head } \\
\text { length }\end{array}$ & 2.35 & 1.2 & 0.8 & 1.73 & 1.4 & 0.9 & 1.56 \\
\hline $\begin{array}{l}C D, \text { fossa } \\
\text { height }\end{array}$ & & 1.25 & & & & & \\
\hline$E F$, head width & 2.5 & 1.5 & 0.75 & 1.82 & 1.55 & 1.1 & 1.58 \\
\hline $\begin{array}{l}\mathrm{GH} \text {, base } \\
\text { width }\end{array}$ & 2.95 & $\begin{array}{l}2.05, \\
\text { est. }\end{array}$ & 1.00 & & 1.85 & 1.25 & 1.8 \\
\hline IJ, base height & 1.75 & 1.0 & 0.7 & 1.5 & 1.15 & 0.9 & 1.19 \\
\hline
\end{tabular}

${ }^{a}$ See Figure 3 for an illustration of the distal phalangeal measurements. 
Table 2. Distal phalangeal ratios ${ }^{a}$

\begin{tabular}{|c|c|c|c|c|c|c|}
\hline Laterals & $\mathrm{AB} / \mathrm{AD}$ & $\mathrm{GH} / \mathrm{AD}$ & $\mathrm{EF} / \mathrm{GH}$ & $E F / A D$ & IJ/AD & $\mathrm{CD} / \mathrm{AD}$ \\
\hline $\begin{array}{l}\text { Hoanghonius } \\
\text { stehlini } \\
\text { IVPP V } 12797\end{array}$ & 0.53 & 0.67 & 0.85 & & 0.40 & \\
\hline $\begin{array}{l}\text { hoanghoniines } \\
\text { mean }(n=4)\end{array}$ & 0.45 & 0.57 & 0.87 & & 0.39 & \\
\hline $\begin{array}{l}\text { Cantius ralstoni } \\
\text { UW } 21454 \text {, UW } \\
21447\end{array}$ & $0.45,0.52$ & $0.58,0.60$ & $0.56,0.60$ & & $0.32,0.33$ & \\
\hline $\begin{array}{l}\text { Notharctus } \\
\text { tenebrosus } \\
\text { AMNH } 127167\end{array}$ & 0.50 & 0.53 & 0.66 & & 0.31 & \\
\hline $\begin{array}{l}\text { Smilodectes } \\
\text { gracilis } \\
\text { USGS } 18338\end{array}$ & 0.49 & 0.61 & 0.72 & & 0.37 & \\
\hline $\begin{array}{l}\text { Adapis parisiensis } \\
\text { UM ECA } 1400\end{array}$ & 0.48 & 0.62 & 0.60 & & 0.57 & \\
\hline \multicolumn{7}{|l|}{$\begin{array}{l}\text { Second Pedal } \\
\text { Digit }\end{array}$} \\
\hline IVPP V 12783.3 & 0.39 & 0.49 & 0.75 & & 0.34 & \\
\hline $\begin{array}{l}\text { Notharctus } \\
\text { tenebrosus } \\
\text { AMNH 143612-03 }\end{array}$ & 0.56 & 0.53 & 0.85 & & 0.42 & \\
\hline \multicolumn{7}{|l|}{ Hallucals } \\
\hline $\begin{array}{l}\text { Eosimias } \\
\text { centennicus } \\
\text { IVVP V } 12798\end{array}$ & 0.35 & est.0.60 & est. 0.73 & 0.44 & 0.29 & \begin{tabular}{|l|}
0.37 \\
\end{tabular} \\
\hline $\begin{array}{l}\text { Teilhardina } \\
\text { brandti } \\
\text { USM } 542001\end{array}$ & 0.37 & \begin{tabular}{|l|} 
est. 0.54 \\
\end{tabular} & \begin{tabular}{|l|} 
est. 0.73 \\
\end{tabular} & 0.41 & 0.26 & 0.45 \\
\hline $\begin{array}{l}\text { Archicebus } \\
\text { achilles } \\
\text { IVPP V } 18618\end{array}$ & 0.39 & 0.51 & 0.73 & & & 0.37 \\
\hline $\begin{array}{l}\text { Omomys carteri } \\
\text { DMNH 52,590 }\end{array}$ & 0.30 & 0.65 & 0.88 & 0.57 & 0.28 & 0.38 \\
\hline $\begin{array}{l}\text { Tarsius syrichta } \\
\text { mean }(n=9)\end{array}$ & 0.40 & 0.78 & 0.74 & 0.57 & 0.41 & 0.40 \\
\hline $\begin{array}{l}\text { Saimiri sciureus } \\
\text { mean }(n=6)\end{array}$ & 0.29 & 0.52 & 0.48 & 0.32 & 0.30 & 0.39 \\
\hline $\begin{array}{l}\text { Cebus apella } \\
\text { mean }(n=3)\end{array}$ & 0.34 & 0.62 & 0.53 & 0.33 & 0.29 & 0.47 \\
\hline $\begin{array}{l}\text { Galagoides } \\
\text { demidovii }(n=3)\end{array}$ & 0.25 & 0.80 & 0.55 & 0.44 & 0.38 & 0.40 \\
\hline $\begin{array}{l}\text { Galago } \\
\text { senegalensis, }(n \\
=9)\end{array}$ & 0.29 & 0.92 & 0.50 & 0.46 & 0.43 & 0.45 \\
\hline
\end{tabular}




\begin{tabular}{|l|l|l|l|l|l|l|}
\hline $\begin{array}{l}\text { Cantius ralstoni } \\
\text { UM } 88330\end{array}$ & 0.43 & 0.68 & 0.73 & & 0.27 & 0.53 \\
\hline
\end{tabular}

${ }^{a} A B / A D$ : head length/absolute length; GH/AD: base width/absolute length; $E F / G H:$ head width/base width; EF/AD: head width/absolute length; IJ/AD: base height/absolute length; CD/AD: fossa height/absolute length 


$$
\begin{array}{r}
12 \\
111 \\
-0-
\end{array}
$$




$$
12
$$



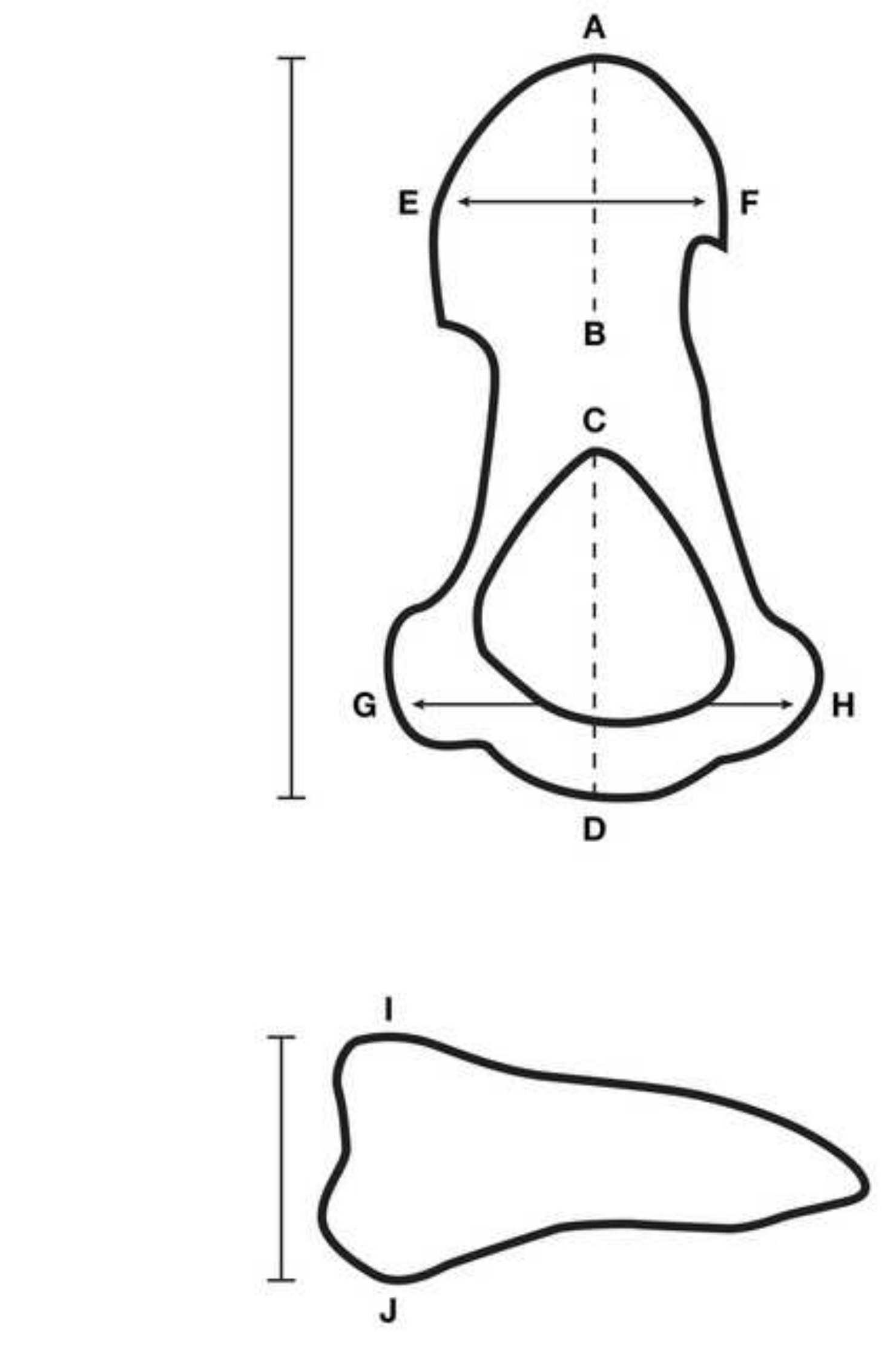

Figure 3

Figure 3

$$
\text { . }
$$

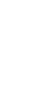




\section{DORSAL VIEW}

\section{DISTAL PHALANX}

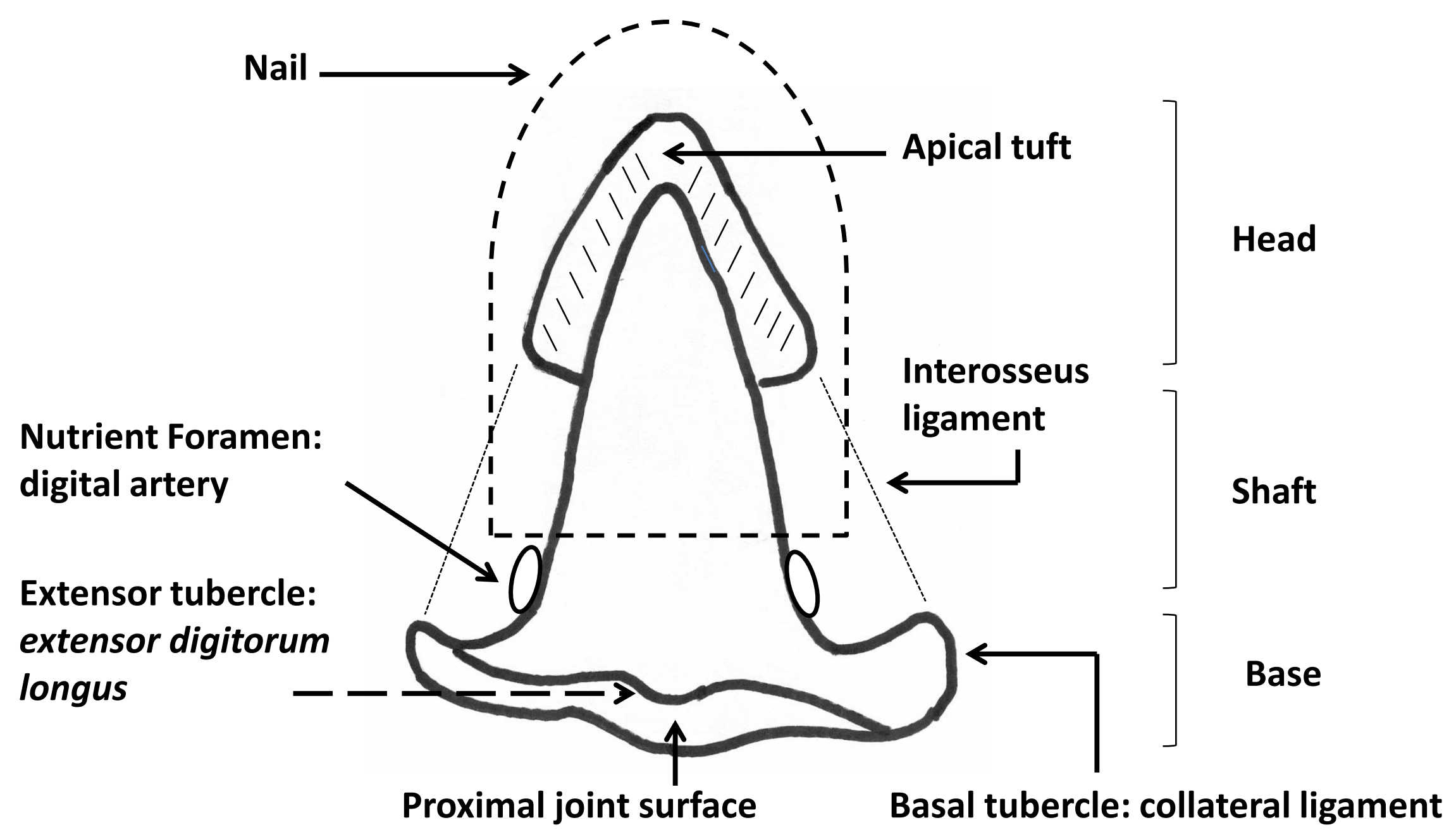




\section{PLANTAR VIEW}

\section{DISTAL PHALANX}

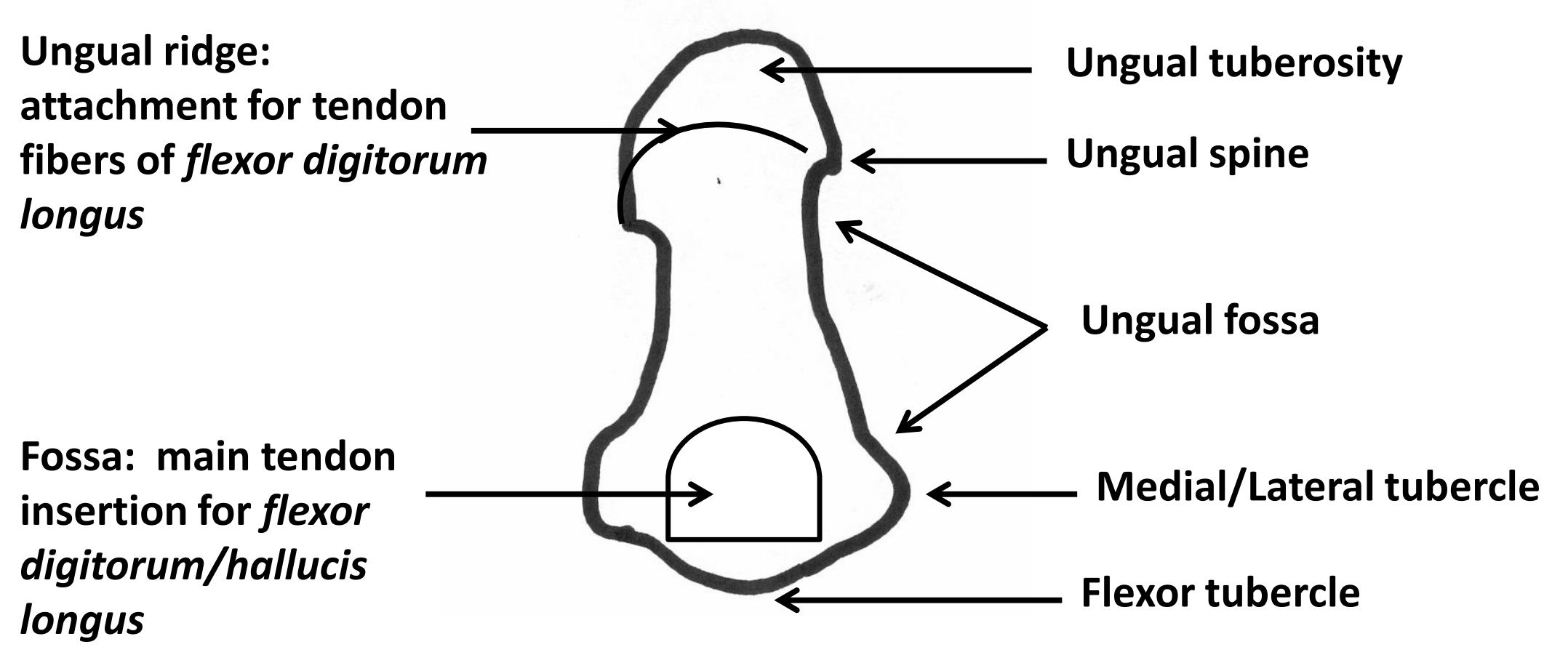

Ungual ridge:

attachment for tendon

fibers of flexor digitorum

longus

Fossa: main tendon insertion for longus 